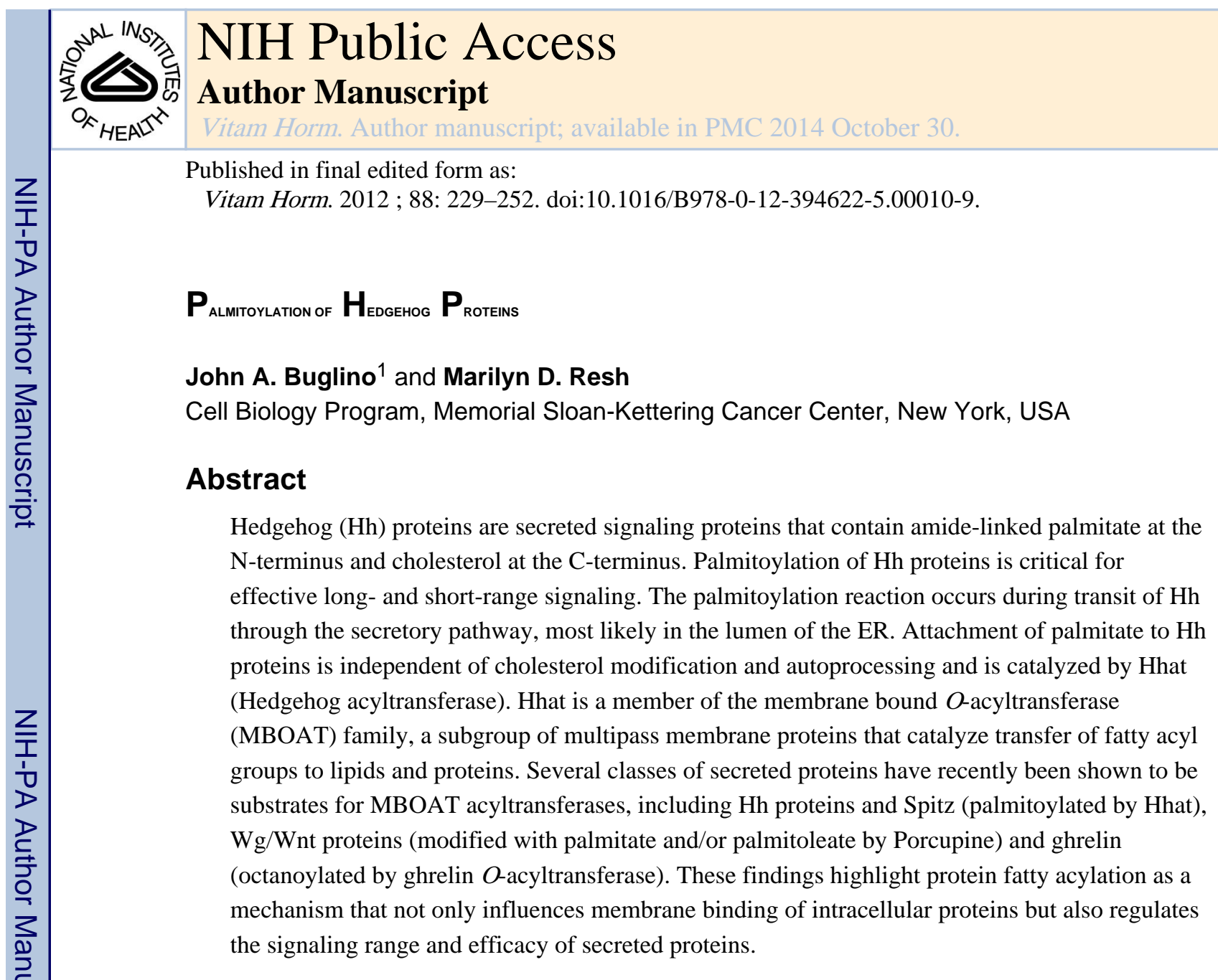

\title{
I. Introduction to $\mathbf{P}_{\text {rotein }} \mathbf{P}_{\text {almitorlation }}$
}

Protein palmitoylation refers to the posttranslational modification of a protein with the 16carbon fatty acid palmitate. In the majority of palmitoylation reactions, the palmitate donor is palmitoyl CoA (Resh, 2006; Smotrys and Linder, 2004). The term protein palmitoylation can also encompass posttranslational modification of proteins with other long chain fatty acids, as many palmitoylated proteins have been observed by mass spectrometry to incorporate heterogeneous mixtures of fatty acids at their modification site (Liang et al., 2001, 2004). In nearly all cases, palmitate is attached to proteins via thioester linkage to a cysteine residue; this is known as $S$-palmitoylation. The labile nature of the thioester linkage in $S$-palmitoylated proteins allows for consecutive rounds of palmitoylation/ depalmitoylation/repalmitoylation in a fashion similar to phosphorylation (Goodwin et al., 2005; Loisel et al., 1999; Lorentzen et al., 2010; Yeh et al., 1999). A small subset of palmitoylated proteins, including the Drosophila epidermal growth factor (EGF) like ligand Spitz (Miura et al., 2006) and Hedgehog (Hh) family members (Chamoun et al., 2001; Pepinsky et al., 1998) are palmitoylated on a cysteine residue that is the N-terminal residue of the mature protein. $N$-Palmitoylation, in contrast to $S$-palmitoylation, is a stable modification. Palmitate attached via amide linkage is essentially as stable and long lived as

(C) Copyright 2012 Elsevier Inc.

${ }^{1}$ Current address: Immunology Program, Memorial Sloan-Kettering Cancer Center, New York, USA. 
the polypeptide backbone peptide bond. $N$-Palmitoylation can be readily distinguished from $S$-palmitoylation via its stability in neutral buffered hydroxylamine. The thioester linkage in $S$-palmitoylated proteins is hydrolyzed by hydroxylamine treatment while the amide linkage in $\mathrm{N}$-palmitoylated proteins is resistant to hydrolysis.

Classes of proteins known to be modified with palmitate include cytoplasmic signaling molecules such as Src family tyrosine kinases (Alland et al., 1994), the Ras family of small GTPases (Hancock et al., 1989), heterotrimeric G-proteins (Kleuss and Krause, 2003), endothelial nitric oxide synthase (E-NOS) (Yeh et al., 1999), and scaffolding proteins (Zhang et al., 1998). Palmitoylation also occurs on several classes of membrane embedded proteins including ion channels (Gubitosi-Klug et al., 2005; Qin et al., 1998), transporters (Singaraja et al., 2009), receptors, and tetraspanins (Resh, 2006). Finally, in addition to intracellular and membrane embedded proteins, palmitate has also been shown to be attached to secreted signaling molecules including Spitz (Miura et al., 2006), members of the Wnt/wingless (Wg) family (Kurayoshi et al., 2007; Willert et al., 2003; Zhai et al., 2004), as well as Drosophila and mammalian Hh family members (Buglino and Resh, 2008; Chamoun et al., 2001; Pepinsky et al., 1998).

Modification with palmitate has been implicated in the regulation of protein trafficking and localization, signal transduction, and enzymatic function. In general, attachment of palmitate increases the hydrophobicity of the modified protein and promotes membrane binding. Palmitoylation also enhances the partitioning of many signaling molecules into lipid rafts. Rafts are liquid ordered microdomains within cellular membranes, and raft association is implicated in mediating efficient signal transduction (Arcaro et al., 2001; Fragoso et al., 2003; Zhang et al., 1998).

\section{II. $\mathbf{P}_{\text {almitovlation of }} \mathbf{H}_{\text {edgehog }} \mathbf{P}_{\text {notems }}$}

The Hh family is the best studied example of palmitoylated, secreted signaling molecules. Drosophila express a single Hh protein, known simply as Hedgehog (Hh) (Nusslein-Volhard and Wieschaus, 1980). There are three Hh family members in mammals, Sonic Hedgehog (Shh), Indian Hedgehog (Ihh), and Desert Hedgehog (Dhh) (Bitgood and McMahon, 1995; Echelard et al., 1993). Signaling by Hh family members plays a major role in embryonic patterning in both flies and mammals (Echelard et al., 1993; Ericson et al., 1995; Heemskerk and DiNardo, 1994; Ma et al., 1993). All Hh family members are thought to be palmitoylated; however, direct incorporation of palmitate to hedgehog in cells has only been documented for Hh and Shh (Buglino and Resh, 2008; Pepinsky et al., 1998). Palmitoylation comprises one of a series of modifications that occur on Hh proteins, as detailed below.

\section{A. Hedgehog biosynthesis, autoprocessing, and cholesterol incorporation}

All Hh family members are initially synthesized as an $\sim 45-\mathrm{kDa}$ precursor protein (Fig. 10.1). The precursor contains an amino-terminal signal sequence that directs entry into the endoplasmic reticulum (Lee et al., 1992). Upon cleavage of the signal sequence, Hh is further processed in the ER by an autoproteolysis reaction catalyzed by the $\mathrm{C}$-terminal half of the molecule (Chen et al., 2011; Lee et al., 1994). Hh autoprocessing occurs via a mechanism similar to that of intein processing in self-splicing proteins (Hall et al., 1997). 
Autoprocessing requires an intact C-terminal domain and can be blocked by mutation of the histidine residue at position 329 or mutation of the cleavage site cysteine (C258) (Porter et al., 1995, 1996a). Shh autoprocessing can also be inhibited by depletion of cellular sterols (Guy, 2000).

The Shh cleavage reaction proceeds via a two-step mechanism. First, the sulfhydryl group of an invariant cysteine residue acts as a nucleophile to attack the carbonyl of the preceding glycine residue resulting in the formation of a thioester intermediate. This thioester linkage

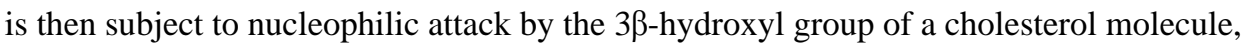
resulting in the liberation of the C-terminal autoprocessing domain and the formation of an ester link between a cholesterol moiety and the carboxyl-terminal glycine residue of the 19kDa amino-terminal fragment (Porter et al., 1996a,b). Cholesterol is the only nucleophile whose incorporation into Hh has been directly observed in vivo. However, other related sterols can replace cholesterol in the autoprocessing reaction in vitro with varying degrees of efficiency (Cooper et al., 1998). From in vitro assays, it is clear that the most important structural feature for autoprocessing is the $\mathrm{C} 3$ hydroxyl moiety. This group must be free of esterified adducts and there is an absolute requirement for the $\beta$ orientation of the alcohol (Cooper et al., 1998). The 19-kDa amino-terminal domain of Hh mediates all known signaling functions of $\mathrm{Hh}$, while the $\mathrm{C}$-terminal autoprocessing domain is primarily responsible for catalyzing autoprocessing and cholesterol incorporation (Fietz et al., 1995; Marti et al., 1995; Porter et al., 1995). Following autocleavage, the C-terminal Shh fragment is rapidly degraded in the ER lumen by the ERAD (ER-associated degradation) pathway (Chen et al., 2011).

\section{B. Hedgehog palmitoylation}

A molecule of palmitate is covalently attached via amide linkage to the amino-terminal cysteine residue of both Hh and Shh (Pepinsky et al., 1998). The 19-kDa amino-terminal fragment of $\mathrm{Hh} / \mathrm{Shh}$ containing both a $\mathrm{C}$-terminal cholesterol and a $\mathrm{N}$-terminal palmitate represents the mature signaling molecule and is the predominant form of $\mathrm{Hh} / \mathrm{Shh}$ secreted in vivo (Taipale et al., 2000). Shh palmitoylation is catalyzed by Hhat (Hedgehog acyltransferase), and this reaction can be recapitulated in cells and in vitro (Buglino and Resh, 2008, 2010).

Palmitoylation of Shh in cells occurs following cleavage of the signal sequence.

Cotransfection of mammalian cells with cDNAs encoding Shh and Hhat reveals several features of the Shh palmitoylation reaction. Shh and Hhat colocalize to the endoplasmic reticulum and the Golgi (Buglino and Resh, 2008). Transit through the secretory pathway is essential, as Shh constructs that lack the N-terminal signal sequence are not palmitoylated (Buglino and Resh, 2008). These findings suggest that palmitoylation of Shh by Hhat occurs intracellularly, in the lumen of secretory organelles. Once the signal sequence is cleaved, cysteine becomes the N-terminal residue and this is the site of modification (Fig. 10.2). Palmitoylation is thought to initially occur via thioester linkage to the cysteine residue. The thioester intermediate then rearranges to an amide linkage via an intramolecular S-to-N shift, producing an amide or N-linked palmitate (Fig. 10.2A) (Mann and Beachy, 2004; Pepinsky et al., 1998). However, in this scenario, the cysteine sulfhydryl group would be regenerated. 
Hhat could attach a second palmitate via a thioester bond, and a thioesterase would be needed to remove the second, thioester linked fatty acid. An alternative mechanism is direct attachment of the palmitate moiety to the N-terminal amide via amide linkage (Fig. 10.2B), analogous to $N$-myristoylation (Farazi et al., 2001). This model is supported by the findings that N-terminally blocked Shh proteins are not substrates for Hhat and that thioester linked palmitoylated intermediates of Shh cannot be detected (Buglino and Resh, 2008). Further studies will be required to define the exact reaction mechanism.

An N-terminal cysteine is required for Shh palmitoylation. Shh mutants with substitutions of either alanine or serine have vastly reduced levels of palmitate incorporation. Signal sequence removal by signal peptidase is therefore absolutely essential as this cleavage event generates the N-terminal cysteine. Attachment of palmitate has been documented on both the $45 \mathrm{kDa}$ Shh precursor protein as well as on the mature $19 \mathrm{kDa}$ form of Shh. Moreover, a Shh mutant that is defective in autoprocessing and cholesterol attachment can still efficiently incorporate palmitate (Buglino and Resh, 2008). Thus, the two lipidation reactions occur independently.

\section{Rasp and Hhat are Hh/Shh palmitoyl acyltransferases}

Genetic studies in Drosophila melanogaster suggested that palmitoylation of Hh was catalyzed by a member of the membrane bound $O$-acyltransferase (MBOAT) family that was independently identified as Skinny Hedgehog, Sightless Hedgehog, Central missing, or Rasp (Amanai and Jiang, 2001; Chamoun et al., 2001; Lee and Treisman, 2001; Micchelli et al., 2002). Rasp is required for induction of Hh target genes and proper patterning of both the Drosophila wing and eye imaginal disks, as well as for proper segmentation of Drosophila larva (Chamoun et al., 2001; Lee and Treisman, 2001; Micchelli et al., 2002). In addition, the rasp null phenotype closely phenocopies mutation of the palmitate acceptor site cysteine within $\mathrm{Hh}$ in the wing imaginal disk. Rasp activity is essential in cells of the posterior compartment that produce $\mathrm{Hh}$ but is not required for Hh transcription or secretion, leading to the stipulation that Rasp functions instead in the maturation of Hh signal (Chamoun et al., 2001; Lee and Treisman, 2001; Micchelli et al., 2002). Rasp mutant organisms display defects in Hh signaling independent of both autoprocessing and cholesterol incorporation, implying that Rasp does not play a role in these processes (Amanai and Jiang, 2001). Additional evidence that Rasp regulates Hh palmitoylation stems from the observation that $\mathrm{Hh}$ is significantly less hydrophobic when isolated from rasp null cells than when isolated from WT cells (Chamoun et al., 2001).

The human homologue of Rasp, originally termed Skinny hedgehog, is known as Hhat (Hedgehog acyltransferase). Loss of Hhat function in the mouse closely phenocopies the mutant phenotype resulting from mutation of the palmitoylation site within Shh when assayed in either the limb or neural tube (Chen et al., 2004). In addition, $\left[{ }^{3} \mathrm{H}\right]$-palmitate labeling of Shh is reduced when Shh is isolated from Hhat null murine embryonic fibroblasts (MEF)'s, consistent with Hhat's putative role in Shh palmitoylation (Chen et al., 2004). Palmitoylation of $\mathrm{Hh} / \mathrm{Shh}$ depends on the presence of a cysteine residue (position 85 in Drosophila, position 24 in human Shh, and position 25 in mouse Shh) immediately following the signal peptide cleavage site and on a functional form of Hhat or Rasp 
(Chamoun et al., 2001; Pepinsky et al., 1998). A Rasp construct with alanine substituted for both the aspartate at position 341 and the histidine at position 381 in tandem is unable to rescue the rasp mutant phenotype, implicating these residues in Rasp activity (Chamoun et al., 2001).

Definitive evidence that Hhat is a palmitoyl acyltransferase for Shh was achieved when Hhat was purified to homogeneity (Buglino and Resh, 2008). Incubation of purified Hhat with purified, recombinant Shh results in near-stoichiometric incorporation of palmitate onto the $\mathrm{N}$-terminal cysteine via amide linkage, features that recapitulate Shh palmitoylation in cells. The reaction occurs catalytically, uses palmitoyl CoA as the palmitate donor, and exhibits optimal activity at $\mathrm{pH}$ 6.5. Hhat appears to be relatively specific for Shh, as other palmitoylated proteins (H-Ras, PSD-95, Wnt proteins) are not substrates for palmitoylation by Hhat in vitro. A peptide containing the first 11 amino acids of the mature Shh sequence is a substrate for Hhat-mediated palmitoylation in vitro, thereby defining a minimal sequence for Shh palmitoylation (Buglino and Resh, 2008). In addition, the Shh substrate must contain an $\mathrm{N}$-terminal cysteine with a free amino terminus, as purified Hhat cannot palmitoylate Shh peptides or proteins if the N-terminus is blocked by acetylation or by a hexa-histidine tag.

\section{Role of palmitoylation in Hh signaling}

The Hh-signaling cascade is utilized throughout development. Hh signaling plays a significant role in patterning of many aspects of the mammalian body plan, including the developing neural tube, limbs, axial skeleton, and induction of ventral forebrain structures (Echelard et al., 1993; Ekker et al., 1995; Ericson et al., 1995; Lopez-Martinez et al., 1995; Roelink et al., 1995). Loss of Hh-signaling activity during vertebrate embryogenesis causes severe developmental disorders such as holoprosencephaly, craniofacial defects, and skeletal malformations (Cooper et al., 1998; Incardona and Roelink, 2000; Lee et al., 2001). In addition to its role in development, Hh has been implicated in the regulation of tissue homeostasis, stem cell biology, and the progression of many types of human malignancies, most notably mebdulloblastoma, pancreatic cancer, and other cancers of the GI tract (Feldmann et al., 2007; Karhadkar et al., 2004; Tian et al., 2009; Yauch et al., 2008).

Palmitoylation of $\mathrm{Hh}$ is required for proper signaling in flies. Mutation of the acceptor site cysteine produces a protein that has little to no patterning activity in Drosophila (Dawber et al., 2005; Lee et al., 2001). Expression of Hh C85S is not sufficient for rescue of the Hh phenotype of Drosophila larva despite the fact that it is expressed at levels similar to WT Hh and is properly autoprocessed. Misexpression of WT Hh in the posterior compartment of the wing disk leads to expansion of the anterior compartment, expanded expression of Hh target genes Ptc and Dpp, and patterning defects in the adult wing. Misexpression of Hh C85A, however, does not result in expansion of the anterior compartment or expanded expression of Patched and dpp in the wing disk, indicating that it is severely attenuated in signaling capacity (Lee et al., 2001).

Mutation of the acceptor cysteine also results in a reduction of Shh signaling in mammalian tissues. However, nonpalmitoylated forms of Shh appear to be more active than their Drosophila counterparts. This is evidenced by the observation that ectopic overexpression of 
Shh C25S is still able to cause polydactyly in the mouse limb (Lee et al., 2001). However, the signaling activity of nonpalmitoylated forms of Shh is clearly reduced in both the mouse limb and neural tube (Chen et al., 2004). In addition, injection of retroviruses encoding WT Shh into the forebrains of E9.5 rats results in severe brain deformities, while retroviruses that encode nonpalmitoylated forms of Shh are unable to cause such defects (Kohtz et al., 2001).

Studies in the mouse embryonic fibroblast line, C3H10T1/2, have revealed that palmitoylation also affects Shh potency in vitro. C3H10T1/2 is a mesenchymal cell line that can be induced under defined conditions to differentiate into adipocytes, chondrocytes, or bone osteoblasts (Pepinsky et al., 1998). Upon differentiation into the bone lineage, there is a marked upregulation of alkaline phosphatase activity, which can be used as a marker for this process (Pepinsky et al., 1998). Treatment of C3H10T1/2 cells with Shh causes a dosedependent increase in alkaline phosphatase activity and is frequently used as a readout of Shh activity in vitro. Palmitoylated forms of Shh are 40-160-fold more active compared to unmodified Shh in this assay (Pepinsky et al., 1998). The enhanced potency of palmitoylated forms of Shh does not correlate with enhanced receptor binding, as palmitoylated and nonpalmitoylated forms of Shh bind equally well to cells expressing Ptc (Pepinsky et al., 1998). The hydrophobic nature of palmitate appears to directly contribute to its ability to enhance Shh-signaling potency. Increasing the hydrophobic character of the amino terminus of Shh, either by introducing a stretch of hydrophobic amino acids or by chemical modification, results in increased potency over WT unmodified forms. By contrast, introduction of hydrophilic residues at the N-terminus of Shh results in reduced signaling in a cell-based differentiation assay (Taylor et al., 2001).

Release of $\mathrm{Hh} / \mathrm{Shh}$ into the media requires the action of Dispatched, a 12-transmembrane (TM) domain containing protein (Burke et al., 1999). Active $\mathrm{Hh} / \mathrm{Shh}$ is released from the producing cell as a multimeric protein, and this process is facilitated by multimerization of $\mathrm{Hh}$ proteins on the cell surface. Dual lipidation enables Hh proteins to form nanoscale oligomers that colocalize with heparin sulfate proteoglycans (HSPGs) (Vyas et al., 2008). Association with HSPGs promotes interaction of Hh proteins with ADAM17, a metalloprotease that has been implicated in Hh shedding from the cell surface (Dierker et al., 2009). A recent study suggests that palmitoylation helps to position the N-terminal region of Shh for ectodomain cleavage by ADAM17 (Ohlig et al., 2011). Proteolytic removal of the palmitoylated $\mathrm{N}$-terminus is proposed to be required for binding of activated Shh to Patched.

After release from the cell, Hh family members act as morphogens that signal in a concentration-dependent manner (Fuccillo et al., 2006; Gritli-Linde et al., 2001; Heemskerk and DiNardo, 1994; Stamataki et al., 2005). Hh responsive cells adopt specific cell fates, or induce different transcriptional profiles, in part depending upon the level of $\mathrm{Hh}$ signal received (Gritli-Linde et al., 2001; Heemskerk and DiNardo, 1994). Hh protein levels and, therefore, signaling are highest at sites of Hh synthesis and decay as the distance between the source of $\mathrm{Hh}$ and the responding cell increases. Forming and maintaining the Hhsignaling gradient is essential for proper patterning of the cuticle in Drosophila, as well as the neural tube and distal limb elements during mammalian development (Gritli-Linde et al., 
2001; Heemskerk and DiNardo, 1994; Lee et al., 2001). Posttranslational lipophilic modifications of the Hh ligand have important effects on the Hh-signaling gradient. Lipophilic modification influences partitioning of Hh proteins into lipoprotein particles, which have been implicated as playing an important role in long range Hh signaling (Callejo et al., 2008; Panakova et al., 2005). Modification of $\mathrm{Hh}$ with cholesterol and palmitate is also required for the formation of soluble multimeric forms of Hh that are freely diffusible, accumulate in a gradient, and enable the molecule to signal over long distances (Chen et al., 2004; Goetz et al., 2006; Zeng et al., 2001).

\section{E. Role of cholesterol modification and autoprocessing in Hh signaling}

Autoprocessing and cholesterol incorporation into $\mathrm{Hh} / \mathrm{Shh}$ are essential for proper tissue distribution and patterning activity. This is evidenced by the observation that several point mutations linked to holoprosencephaly occur within regions of Shh that have been implicated in autoprocessing and cholesterol incorporation (Maity et al., 2005; Roessler et al., 2009). However, Hh/Shh constructs that do not incorporate cholesterol still retain significant signaling activity over both short and long distances (Dawber et al., 2005).

In the initial study characterizing Hh autoprocessing, ectopic overexpression of a cleavage defective form of Hh (H329A) still induced expanded Wg expression during Drosophila embryonic development, although to a lesser degree than when a WT construct was expressed (Lee et al., 1994). This finding suggests that unprocessed Hh is able to signal but in a reduced capacity. Unprocessed forms of Hh were also less active in patterning of dorsal cuticle structures, and in patterning of the wing and eye imaginal disks (Lee et al., 1994; Porter et al., 1995). More recent studies have found that full-length unprocessed $\mathrm{Hh}$ is trafficked to the plasma membrane and can participate in direct cell-to-cell signaling, both in vivo and in vitro, but is unable to act over longer distances (Tokhunts et al., 2009).

The reduction in signaling potential of unprocessed forms of $\mathrm{Hh}$ results from failure to liberate the amino-terminal signaling domain. Overexpression of Hh-N (the 19-kDa Nterminal fragment of Hh unmodified by cholesterol) alone is able to induce similar levels of Wg expression and causes nearly identical changes in dorsal cuticle patterning as full-length Hh (Burke et al., 1999; Porter et al., 1995). Hh-N is also able to rescue most Hh function in the wing imaginal disk (Burke et al., 1999; Dawber et al., 2005). Similarly, Shh-N still retains patterning activity in the mouse limb bud and chick neural tube (Caspary et al., 2002; Yang et al., 1997). In addition, purified recombinant Shh-N constructs lacking cholesterol are still able to bind to Ptc expressing cells and activate Shh signaling in vitro (Taylor et al., 2001). When tested in the C3H10T1/2 differentiation assay, Shh-N lacking cholesterol induced alkaline phosphate upregulation but to a lesser degree than WT Shh (Taylor et al., 2001). Taken together, these findings indicate that modification of $\mathrm{Hh} / \mathrm{Shh}$ with cholesterol enhances signaling potency but is not strictly required for signaling activity in vitro or in vivo.

Incorporation of cholesterol into $\mathrm{Hh} / \mathrm{Shh}$ regulates proper tissue distribution during development. Cholesterol incorporation into $\mathrm{Hh} / \mathrm{Shh}$ restricts diffusion and promotes tethering of the molecule to membranes (Pepinsky et al., 1998). Restriction of Hh/Shh diffusion is essential for forming a steep concentration gradient. Regulated overexpression 
of Hh-N using the GAL4:UAS system results in higher levels of $\mathrm{Wg}$ expression and causes more severe defects in dorsal cuticle patterning when compared to full-length Hh (Porter et al., 1996a). This increased activity was correlated with a more diffuse staining pattern and reduced hydrophobic character of $\mathrm{Hh}-\mathrm{N}$, consistent with the cholesterol moiety acting to restrict the spread of Hh over long distances and promoting high levels of signaling near the site of synthesis. Similarly, reduced spread of cholesterol-modified forms of Hh has also been observed in the Drosophila wing disk (Dawber et al., 2005).

Several lines of evidence suggest that cholesterol incorporation also restricts Shh diffusion in higher eukaryotes. The interaction of Hh with both Dispatched and HSPGs is dependent on cholesterol modification of Hh (Bellaiche et al., 1998; Burke et al., 1999; Kawakami et al., 2002). Cholesterol incorporation has been shown to restrict the spread of Shh within the mouse limb bud (Li et al., 2006). Shh-N constructs were distributed over a broader range and displayed reduced signaling potency within the limb bud when compared to full-length Shh (Li et al., 2006). Similarly, when Shh-N expressed from COS-7 cells was grafted into the chick wing, it was able to diffuse further from the graft site compared to full-length Shh (Yang et al., 1997). Expression of full-length human Shh in high five insect cells produces a cholesterol modified amino-terminal signaling domain which is primarily associated with the cell membrane (Pepinsky et al., 1998). Mass spectrometry analysis of the minor soluble fraction of Shh remaining revealed it to be unmodified by cholesterol (Pepinsky et al., 1998). Taken together, these results indicate that modification of $\mathrm{Hh} / \mathrm{Shh}$ with cholesterol promotes membrane binding and favors short-range signaling. However, it is clear that cholesterol modified forms of Shh are able to directly activate signaling at a distance, and in some cases cholesterol appears to enhance long-range signaling (Briscoe et al., 2001; Wang et al., 2000). Thus, the question arises: how can a hydrophobic modification be required for both short- and long-range signaling?

Two possible mechanisms have been proposed to explain the requirement of cholesterol for efficient long-range Hedgehog signaling. First, cholesterol incorporation into Shh has been implicated in the formation of soluble multimeric forms of Shh (Zeng et al., 2001). Second, cholesterol modification influences the partitioning of Hh into lipoprotein particles (Panakova et al., 2005). Both of these structures would be able to travel longer distances and mediate long-range signaling.

\section{III. $\mathbf{P}_{\text {almitovlation of }} \mathbf{O}_{\text {ther }} \mathbf{S}_{\text {ecreted }} \mathbf{P}_{\text {roteliss }}$}

In addition to Hh family members, at least two other families of secreted signaling molecules have been shown to be palmitoylated: Drosophila EGF receptor (EGFR) ligands and members of the Wnt/Wg family. In both cases, palmitoylation is important for the function of the modified proteins.

\section{A. EGF receptor ligands in flies}

Spitz is a Drosophila EGFR ligand that is required for normal embryonic development, influencing the patterning of the eye, wing, and leg imaginal disks (Freeman, 1994; Miura et al., 2006; Rutledge et al., 1992). Spitz is initially synthesized as a membrane tethered precursor that is secreted following intracellular cleavage by the protease Rhomboid (Urban 
et al., 2001). The mature secreted Spitz molecule is palmitoylated on an N-terminal cysteine residue and it is therefore likely that the palmitate attached to Spitz is amide linked (Miura et al., 2006). Once secreted, palmitoylation of Spitz promotes its association with the extracellular face of the plasma membrane and acts to concentrate Spitz locally at the site of secretion (Miura et al., 2006). This restriction of Spitz diffusion sets up a sharp concentration gradient at the site of synthesis. Palmitoylation is essential for proper Spitz signaling in vivo; nonpalmitoylated forms of Spitz are unable to rescue photoreceptor differentiation. However, palmitoylation of Spitz is not required for receptor binding or activation, as nonpalmitoylated Spitz signals in a fashion indistinguishable from palmitoylated Spitz in vitro (Miura et al., 2006). Two other Drosophila EGF ligands, Keren and Gurken, also contain amino-terminal cysteine residues and are therefore also predicted to be $\mathrm{N}$-palmitoylated (Miura et al., 2006). However, direct incorporation of palmitate into either Keren or Gurken has not yet been demonstrated.

The acyltransferase responsible for Spitz palmitoylation is Rasp (Miura et al., 2006). Mutation of Rasp impairs Spitz signaling in both the eye and wing imaginal disks (Miura et al., 2006). Reduction of rasp mRNA levels by siRNA knockdown reduces the hydrophobic character of Spitz as judged by Triton X-114 detergent phase separation (Miura et al., 2006). In addition, palmitoylation of Spitz in a heterologous system (COS-1 cells) is dependent on coexpression of a functional clone of Rasp (Miura et al., 2006). Taken together, these results support the hypothesis that Rasp mediates Spitz palmitoylation.

\section{B. Wnt and Wg proteins}

Palmitoylation regulates signaling by members of the $\mathrm{Wnt} / \mathrm{Wg}$ family of signaling molecules. Wnt/Wg family members are secreted glycoproteins that play important roles during development as well as in the progression of many types of human malignancies (Beachy et al., 2004). Wnt/Wg proteins are heterogeneously glycosylated and palmitoylated (Tanaka et al., 2002; Willert et al., 2003). Palmitoylation has been directly observed in the case of Wg, Wnt3a, Wnt5a, and Wnt8 (Doubravska et al., 2011; Kurayoshi et al., 2007; Willert et al., 2003; Zhai et al., 2004). Murine Wnt3a is palmitoylated on Cysteine 77 (Willert et al., 2003). This position is conserved in nearly all Wnt proteins, suggesting that other Wnt family members are also likely palmitoylated.

Modification of Wnt3a by palmitate is not essential for secretion or glycosylation of Wnt3a but is required for proper signaling. Both WT and C77A Wnt-3a (a non-palmitoylated mutant) can be efficiently recovered from conditioned media produced by transfected tissue culture cells (Willert et al., 2003). However, non-palmitoylated Wnt3a is compromised in its ability to bind its receptors LRP6 and Frizzled 8 (Komekado et al., 2007). In addition, purified Wnt3a C77A is unable to induce $\beta$-catenin stabilization when added to mouse $\mathrm{L}$ cells, indicating that palmitoylation is essential for Wnt3a signaling (Willert et al., 2003). Palmitoylation serves similar functions in the case of Wnt5a. Preventing palmitoylation of Wnt5a reduces receptor binding and compromises downstream signaling but appears dispensable for secretion (Kurayoshi et al., 2007). By contrast, palmitoylation of Drosophila $\mathrm{Wg}$ at position 93 is essential for Wg secretion. Treatment of Drosophila S2 cells with the inhibitor of protein palmitoylation, 2-bromopalmitate prevents efficient $\mathrm{Wg}$ secretion into 
the culture media (Zhai et al., 2004). In addition, mutation of Cys 93 to Ala compromises secretion of $\mathrm{Wg}$ in the wing imaginal disk (Franch-Marro et al., 2008). The C93A Wg mutant accumulates within the ER, indicating that palmitoylation is essential for intracellular trafficking and secretion of Wg (Franch-Marro et al., 2008).

Wnt3a is also modified with a monounsaturated fatty acid, palmitoleic acid, on Serine 209 (Takada et al., 2006). This position is well conserved within the Wnt/Wg family, suggesting that other family members might be modified in a similar fashion. Palmitoleic acid incorporation is required for efficient palmitoylation of Wnt3 at Cys 77 (Doubravska et al., 2011; Takada et al., 2006). Modification of Wnt3a with palmitoleic acid regulates secretion, as Wnt3a S209A protein is not recovered in the conditioned media of $\mathrm{L}$ cells posttransfection (Takada et al., 2006). As expected given its secretion defect, S209A Wnt3aRNA injected into Xenopus oocytes was unable to cause axis duplication, a hallmark of active Wnt3a signaling (Takada et al., 2006).

Incorporation of palmitoleic acid has yet to be reported for any other member of the Wnt/Wg family. However, the predicted modification site, Ser 239, has been mutated in Drosophila Wg (Franch-Marro et al., 2008). Unlike the equivalent mutation in mouse Wnt3a, Wg S239A was readily secreted (Franch-Marro et al., 2008). Moreover, another Drosophila Wnt homologue, WntD, lacks the putative palmitoleic acid modification site but is still efficiently secreted from both S2 and L cells, indicating that palmitoleic acid modification is not essential for secretion of all $\mathrm{Wnt} / \mathrm{Wg}$ family members (Ching et al., 2008). Mutation of Ser 239 does compromise Wg signaling activity, suggesting that palmitoleic acid incorporation may be important for signaling by both mouse Wnt3a and Drosophila Wg (Franch-Marro et al., 2008).

In addition to influencing secretion and signaling activity, palmitoylation of $\mathrm{Wnt} / \mathrm{Wg}$ proteins also affects their extracellular transport. Enhancing palmitoylation of either Wnt1 or Wnt3a in the chick neural tube by ectopic overexpression of the putative palmitoyl transferase, Porcupine, acts to steepen the Wnt signaling gradient, presumably by preventing diffusion away from the site of secretion (Galli et al., 2007). This result suggests that palmitoylation regulates extracelluar transport of $\mathrm{Wnt} / \mathrm{Wg}$ in a similar fashion to Spitz. However, Wnt family members signal over longer distances. This fact, coupled with the observation that $\mathrm{Wg}$ copurifies with apolipophorins has led to the speculation that palmitoylation promotes Wg incorporation into lipoprotein particles (Panakova et al., 2005). Once incorporated into lipoprotein particles Wg would then be able to travel and signal over longer distances.

\section{IV. $T_{\text {He }}$ MBOAT $F_{\text {amLy of }} A_{\text {cyltransferases }}$}

Two groups of protein palmitoyl acyltransferases (PATs) have been identified. The first, which is responsible for palmitoylation of cytoplasmic and membrane bound proteins, is the DHHC family of PATs (Lobo et al., 2002). This family is named for the presence of a conserved Asp-His-His-Cys motif that is required for activity (Lobo et al., 2002). The second family of PATs, the MBOAT family, mediates attachment of palmitate and other fatty acids to lipid and protein substrates. In particular, the MBOAT family members Hhat, 
Porcupine, and ghrelin $O$-acyltransferase (GOAT) are responsible for fatty acylation of secreted proteins.

\section{A. MBOAT family characteristics}

The MBOAT family of acyltransferases was initially identified by bioinformatics studies. Global sequence alignment algorithms revealed a region of high homology between acyl:CoA cholesterol acyltransferases 1 and 2 (ACAT1/2), the enzymes that catalyze the formation of cholesterol esters, and Porcupine, a segment polarity gene linked to posttranslational modification of $\mathrm{Wnt} / \mathrm{Wg}$ proteins (Hofmann, 2000). The defining characteristics of the MBOAT homology domain are the presence of a highly conserved His residue surrounded by a cluster of hydrophobic residues and a well-conserved Asp/Asn residue surrounded by moderately hydrophobic residues (Hofmann, 2000). Mutation of one or both of these residues compromise enzymatic activity in all family members tested, suggesting that they may be directly involved in catalysis (Bosson et al., 2006; Chamoun et al., 2001; Guo et al., 2005; Lin et al., 2003; Shindou et al., 2009; Yang et al., 2008a).

All members of the MBOAT family are predicted to be multipass membrane proteins containing between 8 and 12 TM segments. Unlike the DHHC family, most MBOAT family members do not function as protein PATs, but rather catalyze transfer of long chain fatty acids to hydroxyl groups of other lipophilic molecules including cholesterol, diacylglycerol, and lysophospholipids (Cases et al., 1998; Chang et al., 1998; Stahl et al., 2008). Members of the MBOAT family are also involved in processing glycosylphosphatidylinositol anchors and the formation of wax esters (Bosson et al., 2006; Yen et al., 2005). In mammalian cells, MBOAT family members with known substrates can be subdivided into three subfamilies based upon substrate preference and/or amino acid homology. These are: (1) the ACAT family, consisting of ACAT1, ACAT2, and DGAT1 (acyl:CoA diacylglycerolacyltransferase 1); (2) the LPLAT (lysophospholipid acyltransferases) family, consisting of MBOAT1, MBOAT2, MBOAT5, MBOAT7; and (3) the PAT family consisting of Porcupine, Hhat, MBOA-4 (GOAT), and the mammalian homologue of glycerol uptake protein-1 (GUP1), also known as Hhat-like (Hhatl).

\section{B. MBOAT family members that acylate protein substrates}

Three members of the MBOAT family have been implicated in the fatty acylation of secreted proteins (Table 10.1). Hhat/Rasp are the palmitoyl acyltransferases for Hh proteins in flies and mammalian cells, and for Spitz in flies (Chamoun et al., 2001). Porcupine has been implicated in Wnt/Wg palmitoylation (Zhai et al., 2004). GOAT mediates incorporation of an octanoyl moiety into the appetite stimulating peptide hormone ghrelin (Gutierrez et al., 2008; Yang et al., 2008a). Biochemical analyses of these proteins are limited primarily due their hydrophobic nature and the difficulty in establishing in vitro assays to monitor fatty acid transfer to substrate proteins.

1. Hhat-Hhat is an $\sim 50 \mathrm{kDa}$ multipass membrane protein that, as described in Section II.C, catalyzes attachment of palmitate to hedgehog proteins. Structure-function analysis of Hhat has begun to define regions and residues that are important for Shh palmitoylation. Transmembrane topology mapping predicts at least eight TM domains in Hhat. Truncation 
mutants that lack one or two TM segments from either the $\mathrm{N}$ - or C-terminal ends of Hhat exhibit reduced stability when expressed in Hhat-transfected cells and are inactive in Shh palmitoylation assays (Buglino and Resh, 2010). Two large loop regions are predicted to be positioned between residues 153-235 and 311-426 in Hhat. Both of these loops contain residues that are highly conserved among MBOAT family members that acylate protein substrates. Deletions or point mutations within these loops reduce Hhat activity without compromising protein stability (Buglino and Resh, 2010). In particular, mutation of the invariant histidine (His379) that is conserved in all MBOAT proteins, reduces palmitoylation activity of Hhat toward Shh by twofold. Kinetic analysis reveals that this mutant binds and transfers palmitoyl CoA as well as the wild-type enzyme, but has an increased $K_{\mathrm{m}}$ and decreased $V_{\max }$ for Shh.

2. Porcupine-Several lines of genetic data suggest that Porcupine mediates modification of Wnt/Wg proteins with both palmitate and palmitoleic acid (Kadowaki et al., 1996; Takada et al., 2006; Willert et al., 2003; Zhai et al., 2004). The porcupine gene was first identified in genetic screens aimed at identifying mutations that affect segment number and polarity during early Drosophila development (Nusslein-Volhard and Wieschaus, 1980). Further analysis of the porcupine mutant phenotype indicated that loss of porcupine function impaired Wg signaling in Drosophila (Kadowaki et al., 1996). Subsequent cloning and characterization of the gene responsible for the porcupine phenotype revealed that it encodes a multipass membrane protein that influences $\mathrm{Wg}$ processing during transit through the secretory pathway (Tanaka et al., 2002). Loss of Porcupine function reduces the hydrophobic character of $\mathrm{Wg}$ as judged by reversed phase chromatography and detergent phase separation (Zhai et al., 2004). In addition, the proportion of Wg present in lipid rafts is reduced when Porcupine function is impaired (Zhai et al., 2004). In mammalian cells, mutation of Porcupine causes a similar reduction in the amount Wnt-3a recovered in the detergent phase after Triton X-114 extraction (Willert et al., 2003). siRNA mediated knockdown of Porcupine inhibits Wnt-3a signaling, indicating that Porcupine is required for Wnt-3a palmitoylation in vivo (Galli et al., 2007). However, direct Porcupine mediated lipophilic modification of Wnt/Wg family member at either site has not yet been observed. Loss of Porcupine function has also been observed to result in alteration in the glycosylation status of Drosophila Wg, but it is not clear if these effects are direct or indirect (Kadowaki et al., 1996; Tanaka et al., 2002).

The C-terminal end of Porcupine has been implicated in $\mathrm{Wg}$ binding. C-terminal truncation mutants of Porcupine fail to Co-IP Wg to the same extent as full-length Porcupine (Tanaka et al., 2002). Apart from this region, no other residues or regions of Porcupine have yet been implicated in the regulation of substrate binding or catalysis.

3. Ghrelin O-acyltransferase-Ghrelin is a small peptide hormone that stimulates growth hormone release from the pituitary and also acts to stimulate appetite (Cummings, 2006; Kamegai et al., 2001; Kojima et al., 1999). Mature ghrelin is modified by an O-linked molecule of octanoic acid on Ser-3, which is essential for all known functions (Kojima et al., 1999). Loss of ghrelin by genetic knockout results in a significant reduction in obesity in mice when challenged with a high-fat diet (Kamegai et al., 2001). This observation has led 
to increased interest in the regulation of ghrelin octanoylation as a potential drug target for prevention of obesity in humans (Cummings, 2006).

Recently, two independent groups identified the enzyme that catalyzes ghrelin octanoylation, GOAT, for ghrelin $O$-acyltransferase (Gutierrez et al., 2008; Yang et al., 2008a). Overexpression of GOAT stimulates ghrelin octanoylation and mice lacking GOAT are devoid of octanoylated ghrelin in circulating blood (Gutierrez et al., 2008; Yang et al., 2008a). These findings indicate that GOAT is the sole mediator of ghrelin octanoylation in vivo. GOAT activity requires the MBOAT homology Asn and His residues, as mutation of either position eliminates GOAT activity both in intact cells as well as in vitro (Yang et al., 2008a,b). Thus far no other regions of GOAT have been implicated in catalysis or substrate binding. However, GOAT mediated octanoylation of ghrelin is influenced by the residues that surround the modification site Ser. Mutation of the Gly at position-1 or the Phe at position-4 results in almost complete inhibition of ghrelin octanoylation (Yang et al., 2008b). These results indicate that the amino-terminal residues of ghrelin serve as a GOAT recognition sites (Ohgusu et al., 2009; Yang et al., 2008b). Further studies have shown that peptides derived from the N-terminus of ghrelin are able to inhibit the octanoylation of fulllength ghrelin. In these studies, octanoylated peptides were two to four times as potent as nonoctanoylated peptides suggesting that GOAT is subject to product inhibition (Yang et al., 2008b).

\section{Conclusions and $F_{\text {uture }} D_{\text {irections }}$}

Palmitoylation has traditionally been viewed as a mechanism to enhance membrane binding of intracellular proteins. It is now clear that secreted proteins, such as Hh, Shh, and Wnt proteins, can be palmitoylated, and that palmitoylation regulates the signaling range and activity of these morphogens in the extracellular space. $\mathrm{Hh} / \mathrm{Shh}$ palmitoylation is catalyzed by Hhat, is independent of autocleavage and cholesterol attachment, and occurs during passage of $\mathrm{Hh} / \mathrm{Shh}$ through the secretory pathway. Hedgehog proteins enter secretory organelles by virtue of their signal sequence, but a mechanism for transporting the other substrate, palmitoyl CoA, into the lumen of the ER and/or Golgi must exist. The active site of Hhat is likely exposed to the ER lumen but details regarding Hhat TM topology remain to be determined. To date, known Hhat substrates include Hedgehog proteins and Spitz, but it is likely that other protein substrates for Hhat exist in flies and mammals. Similarities and differences in how two MBOAT proteins, Hhat and Porcupine, recognize their respective substrates, need to be delineated. We also need a better understanding of how lipidation regulates extracellular gradient formation by palmitoylated morphogens. Finally, identification of activators and inhibitors of Hhat as well as other MBOAT proteins will be useful. A more complete understanding of Hhat enzymology could potentially provide avenues for therapeutic intervention in diseases that require ligand dependent activation of the Hh-signaling cascade for growth and survival.

\section{Acknowledgments}

Research in the authors' laboratory was supported by NIH Grants GM57966, GM008539, and CA 158474. 


\section{REFERENCES}

Alland L, Peseckis SM, Atherton RE, Berthiaume L, Resh MD. Dual myristylation and palmitoylation of Src family member p59fyn affects subcellular localization. J. Biol. Chem. 1994; 269:1670116705. [PubMed: 8206991]

Amanai K, Jiang J. Distinct roles of Central missing and Dispatched in sending the Hedgehog signal. Development. 2001; 128:5119-5127. [PubMed: 11748147]

Arcaro A, Gregoire C, Bakker TR, Baldi L, Jordan M, Goffin L, Boucheron N, Wurm F, van der Merwe PA, Malissen B, Luescher IF. CD8beta endows CD8 with efficient coreceptor function by coupling T cell receptor/CD3 to raft- associated CD8/p56(lck) complexes. J. Exp. Med. 2001; 194:1485-1495. [PubMed: 11714755]

Beachy PA, Karhadkar SS, Berman DM. Tissue repair and stem cell renewal in carcinogenesis. Nature. 2004; 432:324-331. [PubMed: 15549094]

Bellaiche Y, The I, Perrimon N. Tout-velu is a Drosophila homologue of the putative tumour suppressor EXT-1 and is needed for Hh diffusion. Nature. 1998; 394:85-88. [PubMed: 9665133]

Bitgood MJ, McMahon AP. Hedgehog and Bmp genes are coexpressed at many diverse sites of cellcell interaction in the mouse embryo. Dev. Biol. 1995; 172:126-138. [PubMed: 7589793]

Bosson R, Jaquenoud M, Conzelmann A. GUP1 of Saccharomyces cerevisiae encodes an Oacyltransferase involved in remodeling of the GPI anchor. Mol. Biol. Cell. 2006; 17:2636-2645. [PubMed: 16597698]

Briscoe J, Chen Y, Jessell TM, Struhl G. A hedgehog-insensitive form of patched provides evidence for direct long-range morphogen activity of sonic hedgehog in the neural tube. Mol. Cell. 2001; 7:1279-1291. [PubMed: 11430830]

Buglino JA, Resh MD. Hhat is a palmitoylacyltransferase with specificity for N-Palmitoylation of Sonic Hedgehog. J. Biol. Chem. 2008; 283:22076-22088. [PubMed: 18534984]

Buglino JA, Resh MD. Identification of conserved regions and residues within Hedgehog acyltransferase critical for palmitoylation of Sonic Hedgehog. PLoS One. 2010; 5:e11195. [PubMed: 20585641]

Burke R, Nellen D, Bellotto M, Hafen E, Senti KA, Dickson BJ, Basler K. Dispatched, a novel sterolsensing domain protein dedicated to the release of cholesterol-modified hedgehog from signaling cells. Cell. 1999; 99:803-815. [PubMed: 10619433]

Callejo A, Culi J, Guerrero I. Patched, the receptor of Hedgehog, is a lipoprotein receptor. Proc. Natl. Acad. Sci. USA. 2008; 105:912-917. [PubMed: 18198278]

Cases S, Smith SJ, Zheng YW, Myers HM, Lear SR, Sande E, Novak S, Collins C, Welch CB, Lusis AJ, Erickson SK, Farese RV Jr. Identification of a gene encoding an acyl CoA:Diacylglycerol acyltransferase, a key enzyme in triacylglycerol synthesis. Proc. Natl. Acad. Sci. USA. 1998; 95:13018-13023. [PubMed: 9789033]

Caspary T, Garcia-Garcia MJ, Huangfu D, Eggenschwiler JT, Wyler MR, Rakeman AS, Alcorn HL, Anderson KV. Mouse Dispatched homolog1 is required for long-range, but not juxtacrine, Hh signaling. Curr. Biol. 2002; 12:1628-1632. [PubMed: 12372258]

Chamoun Z, Mann RK, Nellen D, von Kessler DP, Bellotto M, Beachy PA, Basler K. Skinny hedgehog, an acyltransferase required for palmitoylation and activity of the hedgehog signal. Science. 2001; 293:2080-2084. [PubMed: 11486055]

Chang CC, Lee CY, Chang ET, Cruz JC, Levesque MC, Chang TY. Recombinant acylCoA:cholesterol acyltransferase-1 (ACAT-1) purified to essential homogeneity utilizes cholesterol in mixed micelles or in vesicles in a highly cooperative manner. J. Biol. Chem. 1998; 273:3513235141. [PubMed: 9857049]

Chen MH, Li YJ, Kawakami T, Xu SM, Chuang PT. Palmitoylation is required for the production of a soluble multimeric Hedgehog protein complex and long-range signaling in vertebrates. Genes Dev. 2004; 18:641-659. [PubMed: 15075292]

Chen X, Tukachinsky H, Huang C-H, Jao C, Chu Y-R, Tang H-Y, Mueller B, Schulman S, Rapoport TA, Salic A. Processing and turnover of the Hedgehog protein in the endoplasmic reticulum. J. Cell Biol. 2011; 192:825-838. [PubMed: 21357747] 
Ching W, Hang HC, Nusse R. Lipid-independent secretion of a Drosophila Wnt protein. J. Biol. Chem. 2008; 283:17092-17098. [PubMed: 18430724]

Cooper MK, Porter JA, Young KE, Beachy PA. Teratogen-mediated inhibition of target tissue response to Shh signaling. Science. 1998; 280:1603-1607. [PubMed: 9616123]

Cummings DE. Ghrelin and the short- and long-term regulation of appetite and body weight. Physiol. Behav. 2006; 89:71-84. [PubMed: 16859720]

Dawber RJ, Hebbes S, Herpers B, Docquier F, van den Heuvel M. Differential range and activity of various forms of the Hedgehog protein. BMC Dev. Biol. 2005; 5:21. [PubMed: 16197551]

Dierker T, Dreier R, Petersen A, Bordych C, Grobe K. Heparan sulfate-modulated, metalloproteasemediated sonic hedgehog release from producing cells. J. Biol. Chem. 2009; 284:8013-8022. [PubMed: 19176481]

Doubravska L, Krausova M, Gradl D, Vojtechova M, Tumora L, Lukas J, Valenta T, Pospichalova V, Fafilek B, Plachy J, Sebesta O, Korinek V. Fatty acid modification of Wnt1 and Wnt3a at serine is prerequisite for lipidation at cysteine and is essential for Wnt signalling. Cell. Signal. 2011; 23:837-848. [PubMed: 21244856]

Echelard Y, Epstein DJ, St-Jacques B, Shen L, Mohler J, McMahon JA, McMahon AP. Sonic hedgehog, a member of a family of putative signaling molecules, is implicated in the regulation of CNS polarity. Cell. 1993; 75:1417-1430. [PubMed: 7916661]

Ekker SC, McGrew LL, Lai CJ, Lee JJ, von Kessler DP, Moon RT, Beachy PA. Distinct expression and shared activities of members of the hedgehog gene family of Xenopus laevis. Development. 1995; 121:2337-2347. [PubMed: 7671800]

Ericson J, Muhr J, Placzek M, Lints T, Jessell TM, Edlund T. Sonic hedgehog induces the differentiation of ventral forebrain neurons: A common signal for ventral patterning within the neural tube. Cell. 1995; 81:747-756. [PubMed: 7774016]

Farazi TA, Waksman G, Gordon JI. The biology and enzymology of protein N-myristoylation. J. Biol. Chem. 2001; 276:39501-39504. [PubMed: 11527981]

Feldmann G, Dhara S, Fendrich V, Bedja D, Beaty R, Mullendore M, Karikari C, Alvarez H, Iacobuzio-Donahue C, Jimeno A, Gabrielson KL, Matsui W, et al. Blockade of hedgehog signaling inhibits pancreatic cancer invasion and metastases: A new paradigm for combination therapy in solid cancers. Cancer Res. 2007; 67:2187-2196. [PubMed: 17332349]

Fietz MJ, Jacinto A, Taylor AM, Alexandre C, Ingham PW. Secretion of the amino-terminal fragment of the hedgehog protein is necessary and sufficient for hedgehog signalling in Drosophila. Curr. Biol. 1995; 5:643-650. [PubMed: 7552175]

Fragoso R, Ren D, Zhang X, Su MW, Burakoff SJ, Jin YJ. Lipid raft distribution of CD4 depends on its palmitoylation and association with Lck, and evidence for CD4-induced lipid raft aggregation as an additional mechanism to enhance CD3 signaling. J. Immunol. 2003; 170:913-921. [PubMed: 12517957]

Franch-Marro X, Wendler F, Griffith J, Maurice MM, Vincent JP. in vivo role of lipid adducts on Wingless. J. Cell Sci. 2008; 121:1587-1592. [PubMed: 18430784]

Freeman M. The spitz gene is required for photoreceptor determination in the Drosophila eye where it interacts with the EGF receptor. Mech. Dev. 1994; 48:25-33. [PubMed: 7833286]

Fuccillo M, Joyner AL, Fishell G. Morphogen to mitogen: The multiple roles of hedgehog signalling in vertebrate neural development. Nat. Rev. Neurosci. 2006; 7:772-783. [PubMed: 16988653]

Galli LM, Barnes TL, Secrest SS, Kadowaki T, Burrus LW. Porcupine-mediated lipid-modification regulates the activity and distribution of Wnt proteins in the chick neural tube. Development. 2007; 134:3339-3348. [PubMed: 17720697]

Goetz JA, Singh S, Suber LM, Kull FJ, Robbins DJ. A highly conserved amino-terminal region of sonic hedgehog is required for the formation of its freely diffusible multimeric form. J. Biol. Chem. 2006; 281:4087-4093. [PubMed: 16339763]

Goodwin JS, Drake KR, Rogers C, Wright L, Lippincott-Schwartz J, Philips MR, Kenworthy AK. Depalmitoylated Ras traffics to and from the Golgi complex via a nonvesicular pathway. J. Cell Biol. 2005; 170:261-272. [PubMed: 16027222] 
Gritli-Linde A, Lewis P, McMahon AP, Linde A. The whereabouts of a morphogen: Direct evidence for short- and graded long-range activity of hedgehog signaling peptides. Dev. Biol. 2001; 236:364-386. [PubMed: 11476578]

Gubitosi-Klug RA, Mancuso DJ, Gross RW. The human Kv1.1 channel is palmitoylated, modulating voltage sensing: Identification of a palmitoylation consensus sequence. Proc. Natl. Acad. Sci. USA. 2005; 102:5964-5968. [PubMed: 15837928]

Guo ZY, Lin S, Heinen JA, Chang CC, Chang TY. The active site His-460 of human acyl-coenzyme A:cholesterol acyltransferase 1 resides in a hitherto undisclosed transmembrane domain. J. Biol. Chem. 2005; 280:37814-37826. [PubMed: 16154994]

Gutierrez JA, Solenberg PJ, Perkins DR, Willency JA, Knierman MD, Jin Z, Witcher DR, Luo S, Onyia JE, Hale JE. Ghrelin octanoylation mediated by an orphan lipid transferase. Proc. Natl. Acad. Sci. USA. 2008; 105:6320-6325. [PubMed: 18443287]

Guy RK. Inhibition of sonic hedgehog autoprocessing in cultured mammalian cells by sterol deprivation. Proc. Natl. Acad. Sci. USA. 2000; 97:7307-7312. [PubMed: 10860995]

Hall TM, Porter JA, Young KE, Koonin EV, Beachy PA, Leahy DJ. Crystal structure of a Hedgehog autoprocessing domain: Homology between Hedgehog and self-splicing proteins. Cell. 1997; 91:85-97. [PubMed: 9335337]

Hancock JF, Magee AI, Childs JE, Marshall CJ. All ras proteins are polyisoprenylated but only some are palmitoylated. Cell. 1989; 57:1167-1177. [PubMed: 2661017]

Heemskerk J, DiNardo S. Drosophila hedgehog acts as a morphogen in cellular patterning. Cell. 1994; 76:449-460. [PubMed: 8313468]

Hofmann K. A superfamily of membrane-bound O-acyltransferases with implications for wnt signaling. Trends Biochem. Sci. 2000; 25:111-112. [PubMed: 10694878]

Incardona JP, Roelink H. The role of cholesterol in Shh signaling and teratogen-induced holoprosencephaly. Cell. Mol. Life Sci. 2000; 57:1709-1719. [PubMed: 11130177]

Kadowaki T, Wilder E, Klingensmith J, Zachary K, Perrimon N. The segment polarity gene porcupine encodes a putative multitransmembrane protein involved in Wingless processing. Genes Dev. 1996; 10:3116-3128. [PubMed: 8985181]

Kamegai J, Tamura H, Shimizu T, Ishii S, Sugihara H, Wakabayashi I. Chronic central infusion of ghrelin increases hypothalamic neuropeptide Y and Agouti-related protein mRNA levels and body weight in rats. Diabetes. 2001; 50:2438-2443. [PubMed: 11679419]

Karhadkar SS, Bova GS, Abdallah N, Dhara S, Gardner D, Maitra A, Isaacs JT, Berman DM, Beachy PA. Hedgehog signalling in prostate regeneration, neoplasia and metastasis. Nature. 2004; 431:707-712. [PubMed: 15361885]

Kawakami T, Kawcak T, Li YJ, Zhang W, Hu Y, Chuang PT. Mouse dispatched mutants fail to distribute hedgehog proteins and are defective in hedgehog signaling. Development. 2002; 129:5753-5765. [PubMed: 12421714]

Kleuss C, Krause E. Galpha(s) is palmitoylated at the N-terminal glycine. EMBO J. 2003; 22:826-832. [PubMed: 12574119]

Kohtz JD, Lee HY, Gaiano N, Segal J, Ng E, Larson T, Baker DP, Garber EA, Williams KP, Fishell G. N-terminal fatty-acylation of sonic hedgehog enhances the induction of rodent ventral forebrain neurons. Development. 2001; 128:2351-2363. [PubMed: 11493554]

Kojima M, Hosoda H, Date Y, Nakazato M, Matsuo H, Kangawa K. Ghrelin is a growth-hormonereleasing acylated peptide from stomach. Nature. 1999; 402:656-660. [PubMed: 10604470]

Komekado H, Yamamoto H, Chiba T, Kikuchi A. Glycosylation and palmitoylation of Wnt-3a are coupled to produce an active form of Wnt-3a. Genes Cells. 2007; 12:521-534. [PubMed: 17397399]

Kurayoshi M, Yamamoto H, Izumi S, Kikuchi A. Post-translational palmitoylation and glycosylation of Wnt-5a are necessary for its signalling. Biochem. J. 2007; 402:515-523. [PubMed: 17117926]

Lee JD, Treisman JE. Sightless has homology to transmembrane acyltransferases and is required to generate active Hedgehog protein. Curr. Biol. 2001; 11:1147-1152. [PubMed: 11509241]

Lee JJ, von Kessler DP, Parks S, Beachy PA. Secretion and localized transcription suggest a role in positional signaling for products of the segmentation gene hedgehog. Cell. 1992; 71:33-50. [PubMed: 1394430] 
Lee JJ, Ekker SC, von Kessler DP, Porter JA, Sun BI, Beachy PA. Autoproteolysis in hedgehog protein biogenesis. Science. 1994; 266:1528-1537. [PubMed: 7985023]

Lee JD, Kraus P, Gaiano N, Nery S, Kohtz J, Fishell G, Loomis CA, Treisman JE. An acylatable residue of Hedgehog is differentially required in Drosophila and mouse limb development. Dev. Biol. 2001; 233:122-136. [PubMed: 11319862]

Li Y, Zhang H, Litingtung Y, Chiang C. Cholesterol modification restricts the spread of Shh gradient in the limb bud. Proc. Natl. Acad. Sci. USA. 2006; 103:6548-6553. [PubMed: 16611729]

Liang X, Nazarian A, Erdjument-Bromage H, Bornmann W, Tempst P, Resh MD. Heterogeneous fatty acylation of Src family kinases with polyunsaturated fatty acids regulates raft localization and signal transduction. J. Biol. Chem. 2001; 276:30987-30994. [PubMed: 11423543]

Liang X, Lu Y, Wilkes M, Neubert TA, Resh MD. The N-terminal SH4 region of the Src family kinase Fyn is modified by methylation and heterogeneous fatty acylation: Role in membrane targeting, cell adhesion, and spreading. J. Biol. Chem. 2004; 279:8133-8139. [PubMed: 14660555]

Lin S, Lu X, Chang CC, Chang TY. Human acyl-coenzyme A: cholesterol acyltransferase expressed in chinese hamster ovary cells: Membrane topology and active site location. Mol. Biol. Cell. 2003; 14:2447-2460. [PubMed: 12808042]

Lobo S, Greentree WK, Linder ME, Deschenes RJ. Identification of a Ras palmitoyltransferase in Saccharomyces cerevisiae. J. Biol. Chem. 2002; 277:41268-41273. [PubMed: 12193598]

Loisel TP, Ansanay H, Adam L, Marullo S, Seifert R, Lagace M, Bouvier M. Activation of the beta(2)-adrenergic receptor-Galpha(s) complex leads to rapid depalmitoylation and inhibition of repalmitoylation of both the receptor and Galpha(s). J. Biol. Chem. 1999; 274:31014-31019. [PubMed: 10521499]

Lopez-Martinez A, Chang DT, Chiang C, Porter JA, Ros MA, Simandl BK, Beachy PA, Fallon JF. Limb-patterning activity and restricted posterior localization of the amino-terminal product of Sonic hedgehog cleavage. Curr. Biol. 1995; 5:791-796. [PubMed: 7583126]

Lorentzen A, Kinkhabwala A, Rocks O, Vartak N, Bastiaens PI. Regulation of Ras localization by acylation enables a mode of intracellular signal propagation. Sci. Signal. 2010; 3:ra68. [PubMed: 20858867]

Ma C, Zhou Y, Beachy PA, Moses K. The segment polarity gene hedgehog is required for progression of the morphogenetic furrow in the developing Drosophila eye. Cell. 1993; 75:927-938. [PubMed: 8252628]

Maity T, Fuse N, Beachy PA. Molecular mechanisms of Sonic hedgehog mutant effects in holoprosencephaly. Proc. Natl. Acad. Sci. USA. 2005; 102:17026-17031. [PubMed: 16282375]

Mann RK, Beachy PA. Novel lipid modifications of secreted protein signals. Annu. Rev. Biochem. 2004; 73:891-923. [PubMed: 15189162]

Marti E, Bumcrot DA, Takada R, McMahon AP. Requirement of 19K form of Sonic hedgehog for induction of distinct ventral cell types in CNS explants. Nature. 1995; 375:322-325. [PubMed: 7753196]

Micchelli CA, The I, Selva E, Mogila V, Perrimon N. Rasp, a putative transmembrane acyltransferase, is required for Hedgehog signaling. Development. 2002; 129:843-851. [PubMed: 11861468]

Miura GI, Buglino J, Alvarado D, Lemmon MA, Resh MD, Treisman JE. Palmitoylation of the EGFR ligand Spitz by Rasp increases Spitz activity by restricting its diffusion. Dev. Cell. 2006; 10:167176. [PubMed: 16459296]

Nusslein-Volhard C, Wieschaus E. Mutations affecting segment number and polarity in Drosophila. Nature. 1980; 287:795-801. [PubMed: 6776413]

Ohgusu H, Shirouzu K, Nakamura Y, Nakashima Y, Ida T, Sato T, Kojima M. Ghrelin Oacyltransferase (GOAT) has a preference for n-hexanoyl-CoA over n-octanoyl-CoA as an acyl donor. Biochem. Biophys. Res. Commun. 2009; 386:153-158. [PubMed: 19501572]

Ohlig S, Farshi P, Pckhinke U, van den Boom J, Hoing S, Jakuschev S, Hoffmann D, Dreier R, Scholer HR, Dierker T, Bordych C, Grobe K. Dev. Cell. 2011; 20:764-774.

Panakova D, Sprong H, Marois E, Thiele C, Eaton S. Lipoprotein particles are required for Hedgehog and Wingless signalling. Nature. 2005; 435:58-65. [PubMed: 15875013] 
Pepinsky RB, Zeng C, Wen D, Rayhorn P, Baker DP, Williams KP, Bixler SA, Ambrose CM, Garber EA, Miatkowski K, Taylor FR, Wang EA, et al. Identification of a palmitic acid-modified form of human Sonic hedgehog. J. Biol. Chem. 273:14037-14045. 1998. [PubMed: 9593755]

Porter JA, von Kessler DP, Ekker SC, Young KE, Lee JJ, Moses K, Beachy PA. The product of hedgehog autoproteolytic cleavage active in local and long-range signalling. Nature. 1995; 374:363-366. [PubMed: 7885476]

Porter JA, Ekker SC, Park WJ, von Kessler DP, Young KE, Chen CH, Ma Y, Woods AS, Cotter RJ, Koonin EV, Beachy PA. Hedgehog patterning activity: Role of a lipophilic modification mediated by the carboxy-terminal autoprocessing domain. Cell. 1996a; 86:21-34. [PubMed: 8689684]

Porter JA, Young KE, Beachy PA. Cholesterol modification of hedgehog signaling proteins in animal development. Science. 1996b; 274:255-259. [PubMed: 8824192]

Qin N, Platano D, Olcese R, Costantin JL, Stefani E, Birnbaumer L. Unique regulatory properties of the type $2 \mathrm{a} \mathrm{Ca} 2+$ channel beta subunit caused by palmitoylation. Proc. Natl. Acad. Sci. USA. 1998; 95:4690-4695. [PubMed: 9539800]

Resh MD. Palmitoylation of ligands, receptors, and intracellular signaling molecules. Sci. STKE. 2006; 2006; 14

Roelink H, Porter JA, Chiang C, Tanabe Y, Chang DT, Beachy PA, Jessell TM. Floor plate and motor neuron induction by different concentrations of the amino-terminal cleavage product of sonic hedgehog autoproteolysis. Cell. 1995; 81:445-455. [PubMed: 7736596]

Roessler E, El-Jaick KB, Dubourg C, Velez JI, Solomon BD, Pineda-Alvarez DE, Lacbawan F, Zhou N, Ouspenskaia M, Paulussen A, Smeets HJ, Hehr U, et al. The mutational spectrum of holoprosencephaly-associated changes within the SHH gene in humans predicts loss-of-function through either key structural alterations of the ligand or its altered synthesis. Hum. Mutat. 2009; 30:E921-E935. [PubMed: 19603532]

Rutledge BJ, Zhang K, Bier E, Jan YN, Perrimon N. The Drosophila spitz gene encodes a putative EGF-like growth factor involved in dorsal-ventral axis formation and neurogenesis. Genes Dev. 1992; 6:1503-1517. [PubMed: 1644292]

Shindou H, Eto M, Morimoto R, Shimizu T. Identification of membrane O-acyltransferase family motifs. Biochem. Biophys. Res. Commun. 2009; 383:320-325. [PubMed: 19361486]

Singaraja RR, Kang MH, Vaid K, Sanders SS, Vilas GL, Arstikaitis P, Coutinho J, Drisdel RC, ElHusseini Ael D, Green WN, Berthiaume L, Hayden MR. Palmitoylation of ATP-binding cassette transporter A1 is essential for its trafficking and function. Circ. Res. 2009; 105:138-147. [PubMed: 19556522]

Smotrys JE, Linder ME. Palmitoylation of intracellular signaling proteins: Regulation and function. Annu. Rev. Biochem. 2004; 73:559-587. [PubMed: 15189153]

Stahl U, Stalberg K, Stymne S, Ronne H. A family of eukaryotic lysophospholipid acyltransferases with broad specificity. FEBS Lett. 2008; 582:305-309. [PubMed: 18154737]

Stamataki D, Ulloa F, Tsoni SV, Mynett A, Briscoe J. A gradient of Gli activity mediates graded Sonic Hedgehog signaling in the neural tube. Genes Dev. 2005; 19:626-641. [PubMed: 15741323]

Taipale J, Chen JK, Cooper MK, Wang B, Mann RK, Milenkovic L, Scott MP, Beachy PA. Effects of oncogenic mutations in Smoothened and Patched can be reversed by cyclopamine. Nature. 2000; 406:1005-1009. [PubMed: 10984056]

Takada R, Satomi Y, Kurata T, Ueno N, Norioka S, Kondoh H, Takao T, Takada S. Monounsaturated fatty acid modification of Wnt protein: Its role in Wnt secretion. Dev. Cell. 2006; 11:791-801. [PubMed: 17141155]

Tanaka K, Kitagawa Y, Kadowaki T. Drosophila segment polarity gene product porcupine stimulates the posttranslational N-glycosylation of wingless in the endoplasmic reticulum. J. Biol. Chem. 2002; 277:12816-12823. [PubMed: 11821428]

Taylor FR, Wen D, Garber EA, Carmillo AN, Baker DP, Arduini RM, Williams KP, Weinreb PH, Rayhorn P, Hronowski X, Whitty A, Day ES, et al. Enhanced potency of human Sonic hedgehog by hydrophobic modification. Biochemistry. 1998; 40:4359-4371. [PubMed: 11284692]

Tian H, Callahan CA, DuPree KJ, Darbonne WC, Ahn CP, Scales SJ, de Sauvage FJ. Hedgehog signaling is restricted to the stromal compartment during pancreatic carcinogenesis. Proc. Natl. Acad. Sci. USA. 2009; 106:4254-4259. [PubMed: 19246386] 
Tokhunts R, Singh S, Chu T, D’Angelo G, Baubet V, Goetz JA, Huang Z, Yuan Z, Ascano M, Zavros $\mathrm{Y}$, Therond PP, Kunes $\mathrm{S}$, et al. The full-length unprocessed hedgehog protein is an active signaling molecule. J. Biol. Chem. 2009; 285:2562-2568. [PubMed: 19920144]

Urban S, Lee JR, Freeman M. Drosophila rhomboid-1 defines a family of putative intramembrane serine proteases. Cell. 2001; 107:173-182. [PubMed: 11672525]

Vyas N, Goswami D, Manonmani A, Sharma P, Ranganath HA, VijayRaghaven K, Shashidhara LS, Sowdhamini R, Mayor S. Nanoscale organization of hedgehog is essential for long-range signaling. Cell. 2008; 133:1214-1227. [PubMed: 18585355]

Wang B, Fallon JF, Beachy PA. Hedgehog-regulated processing of Gli3 produces an anterior/posterior repressor gradient in the developing vertebrate limb. Cell. 2000; 100:423-434. [PubMed: 10693759]

Willert K, Brown JD, Danenberg E, Duncan AW, Weissman IL, Reya T, Yates JR 3rd, Nusse R. Wnt proteins are lipid-modified and can act as stem cell growth factors. Nature. 2003; 423:448-452. [PubMed: 12717451]

Yang Y, Drossopoulou G, Chuang PT, Duprez D, Marti E, Bumcrot D, Vargesson N, Clarke J, Niswander L, McMahon A, Tickle C. Relationship between dose, distance and time in Sonic Hedgehog-mediated regulation of anteroposterior polarity in the chick limb. Development. 1997; 124:4393-4404. [PubMed: 9334287]

Yang J, Brown MS, Liang G, Grishin NV, Goldstein JL. Identification of the acyltransferase that octanoylates ghrelin, an appetite-stimulating peptide hormone. Cell. 2008a; 132:387-396. [PubMed: 18267071]

Yang J, Zhao TJ, Goldstein JL, Brown MS. Inhibition of ghrelin O-acyltransferase (GOAT) by octanoylated pentapeptides. Proc. Natl. Acad. Sci. USA. 2008b; 105:10750-10755. [PubMed: 18669668]

Yauch RL, Gould SE, Scales SJ, Tang T, Tian H, Ahn CP, Marshall D, Fu L, Januario T, Kallop D, Nannini-Pepe M, Kotkow K, et al. A paracrine requirement for hedgehog signalling in cancer. Nature. 2008; 455:406-410. [PubMed: 18754008]

Yeh DC, Duncan JA, Yamashita S, Michel T. Depalmitoylation of endothelial nitric-oxide synthase by acyl-protein thioesterase 1 is potentiated by $\mathrm{Ca}(2+)$-calmodulin. J. Biol. Chem. 1999; 274:33148-33154. [PubMed: 10551886]

Yen CL, Monetti M, Burri BJ, Farese RV Jr. The triacylglycerol synthesis enzyme DGAT1 also catalyzes the synthesis of diacylglycerols, waxes, and retinyl esters. J. Lipid Res. 2005; 46:15021511. [PubMed: 15834126]

Zeng X, Goetz JA, Suber LM, Scott WJ Jr. Schreiner CM, Robbins DJ. A freely diffusible form of Sonic hedgehog mediates long-range signalling. Nature. 2001; 411:716-720. [PubMed: 11395778]

Zhai L, Chaturvedi D, Cumberledge S. Drosophila wnt-1 undergoes a hydrophobic modification and is targeted to lipid rafts, a process that requires porcupine. J. Biol. Chem. 2004; 279:33220-33227. [PubMed: 15166250]

Zhang W, Trible RP, Samelson LE. LAT palmitoylation: Its essential role in membrane microdomain targeting and tyrosine phosphorylation during T cell activation. Immunity. 1998; 9:239-246. [PubMed: 9729044] 

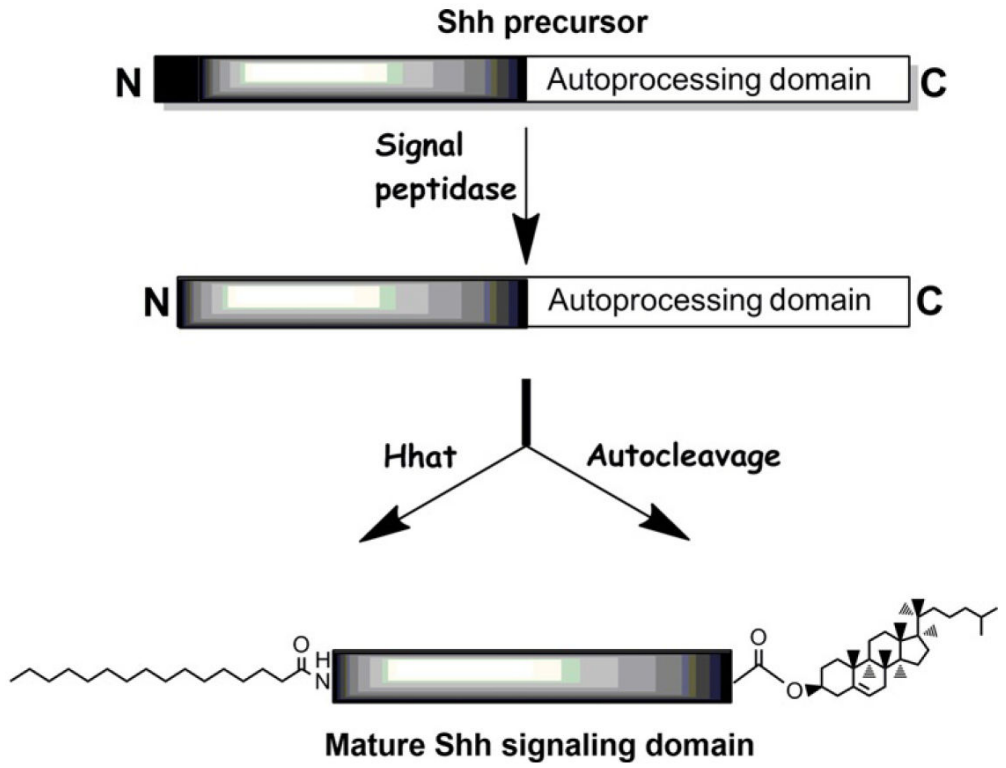

Figure 10.1.

Multiple processing events generate the mature Shh signaling protein. Signal peptidase removes the $\mathrm{N}$-terminal signal sequence. The autoprocessing domain mediates autocleavage and attachment of cholesterol to the C-terminus of the Shh signaling domain, while Hhat catalyzes attachment of palmitate via amide linkage to the N-terminus of the Shh signaling domain. 
A
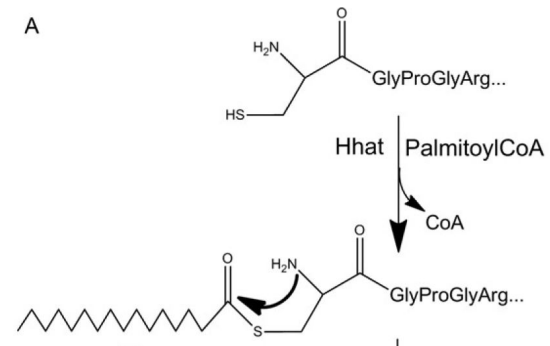

(1)
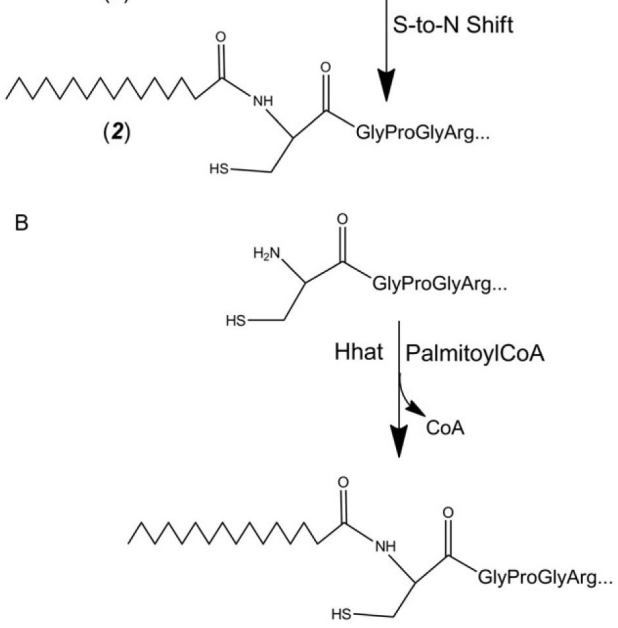

Figure 10.2.

Potential mechanisms for Hhat-mediated $\mathrm{N}$-Palmitoylation of Hedgehog proteins. (A) Formation of a thioester intermediate (1) is followed by an S-to-N intramolecular shift and generation of the amide-linked, palmitoylated hedgehog protein (2). (B) Alternatively, Hhat could catalyze direct attachment of palmitate via amide bond to the amine group of the $\mathrm{N}$ terminal cysteine. 
Table 10.1

MBOAT family members that catalyze attachment of fatty acids to proteins

\begin{tabular}{|lll|}
\hline Enzyme & Protein substrate & Fatty acid substrate \\
Hhat & Shh, Ihh, Dhh & Palmitate (16:0) \\
Rasp & Hh, Spitz, Keren, Gerken & Palmitate (16:0) \\
Porcupine & Wg and Wnt proteins & Palmitate (16:0) \\
& & Palmitoleic (16:1) \\
GOAT & Ghrelin & Octanoate (8:0) \\
\hline
\end{tabular}

